\title{
DETERMINATION OF ANTIOXIDANT CAPACITY (ORAC) OF GREIGIA SPHACELATA AND CORRELATION WITH VOLTAMMETRIC METHODS
}

\author{
FELIPE ARAVENA-SANHUEZA ${ }^{a}$, MÓNICA PÉREZ-RIVERA $^{a}$, ROSARIO CASTILLO-FELICES ${ }^{b}$, \\ RODOLFO MUNDACA-URIBE ${ }^{b}$, MARIO ARANDA BUSTOS ${ }^{c}$ AND CARLOS PEÑA FARFAL ${ }^{d *}$
}

\author{
${ }^{a}$ Facultad de Ciencias Químicas, Universidad de Concepción, Edmundo Larenas 129, 4070371-Concepción, CHILE. \\ ${ }^{b}$ Facultad de Farmacia, Universidad de Concepción, Barrio Universitario SN, 4070043-Concepcion, CHILE. \\ ${ }^{c}$ Facultad de Química y de Farmacia, Pontificia Universidad Católica de Chile, Av. Vicuña Mackenna 4860, 7820436-Macul, Santiago, CHILE. \\ ${ }^{d}$ Instituto de Ciencias Químicas Aplicadas, Facultad de Ingeniería, Universidad Autónoma de Chile, Av. Alemania 01090, 4810101-Temuco, CHILE.
}

\begin{abstract}
The study and determination of the antioxidant capacity of the Greigia Sphacelata fruit were carried out. G. sphacelata is an endemic fruit of central-southern Chile, better known as Chupón or Quiscal. Spectrophotometric and modified ORAC test were developed for antioxidant capacity determinations, and later an electrochemical method was developed by differential impulse voltammetry (DPV) with a vitreous carbon electrode for the quantification of the antioxidant capacity expressed in equivalent of the Trolox standard in $\mu \mathrm{molL}^{-1}$. Once the voltammetric test was developed, the correlation study between both methods used to determine the antioxidant capacity of Greigia sphacelata was carried out. The results of the determination of the antioxidant capacity of Greigia sphacelata by ORAC test report an antioxidant capacity of $3525 \mu \mathrm{mol} / 100 \mathrm{~g}$ equivalents of Trolox. Concerning the concentration obtained by the electrochemical methodology, $724 \mu \mathrm{mol} / 100 \mathrm{~g}$ Trolox equivalents is obtained for a linear correlation $r=0.969$ with the spectrophotometric method.
\end{abstract}

Keywords: Antioxidants, ORAC, Greigia sphacelata, DPV.

\section{INTRODUCTION}

Antioxidants are redox substances that behave as reducing agents, and they are defined as natural or synthetic substances that can prevent or delay oxidative cell damage caused by physiological oxidants. Among them are reactive oxygen species (ROS) generated through the partial reduction of molecular oxygen as by-products of numerous metabolic pathways, which occurs mainly in mitochondria[1], reactive nitrogen species ( RNS), and free radicals [2], by donating a hydrogen atom or an electron.

It has been shown in the last 30 years that the intake of foods such as fruits, vegetables, and beverages of plant origin has positive effects for the prevention of various types of diseases thanks to the presence of antioxidant compounds $[3,4]$.

The main antioxidant action mechanisms are classified into mechanisms based on hydrogen atom transfer (HAT)[5]), electron transfer (SET), and mixed mechanisms (HAT / SET) [6]. Essentially non-enzymatic antioxidants, endogenous or ingested through the diet, are guided by this mechanism of action, causing the antioxidant compound to become a free radical and subsequently oxidize to a form that is of very low reactivity towards its environment.

The ORAC (oxygen radical absorption capacity) test is a fluorescence method that measures the oxidative degradation of a fluorescent molecule after mixing with a free radical initiator, which initially used AAPH (2,2'azobis (2 methylpropinamide) dihydrochloride) as a generator of free radicals and fluorescein as a target molecule. $[7,8,9]$. Method that has been modified to also be developed spectrophotometrically using pyrogallol red (PGR) as the target molecule, obtaining results on par with those performed using fluorescence [5]. The ORAC index is evaluated from the area under the curve of the kinetic profiles of the target molecule, and generally uses gallic acid or Trolox (a watersoluble analog of vitamin E) as a reference standard; thus, the ORAC value is expressed in Trolox equivalents [7]

Antioxidants are electrochemically active (SET mechanism), so in recent years tests have been developed to determine the antioxidant capacity in various matrices, preferably in fruits, vegetables, and beverages of natural origin, by means of electrochemical techniques or methods such as tests based on in cyclic voltammetry $(\mathrm{CV})$, pulse differential (DPV) and square wave (SWV). [10, 11,12 ], being the cyclic voltammetry is most widely used [13]), being able to use a diverse range of electrodes (vitrified carbon, gold, platinum) and materials to modify their surface, mainly enzymes and gold nanoparticles.

These assays have received greater interest due to their rapid detection capacity, sensitivity, and economic profitability compared to peer assays, in addition to using traditional standards such as gallic acid, ascorbic acid, and Trolox [14].

The genus Greigia belonging to the Bromeliaceae family[15] is recognized by the Chilean species Greigia sphacelata, commonly known as Chupón or Quiscal. Currently, 32 species of Greigia are recognized, which grow in humid habitats, at the foot of native trees (Andean forest), at the bottom of streams in countries such as Colombia, Venezuela, Peru, Ecuador, Central America, and southern Mexico.

Chile has four endemic species; three are found from the north-south of the country starting in the Maule region towards the south of Chiloe[16], species Greigia sphacelata, G. landbeckiia, and G. pearcei (Figure 1), and Greigia berteroi, which is endemic from Robinson Crusoe Island [17]
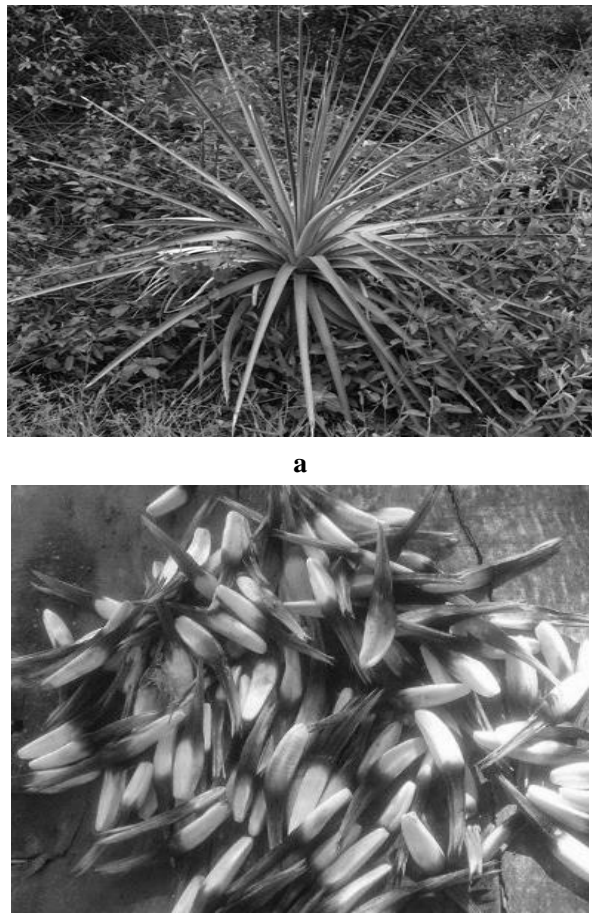

b

Figure 1: Greigia sphacelata a) Plant ; b) Fruit (known as Chupón) 
Greigia sphacelata can reach up to 5 meters in height and generates a small fruit, an elongated edible berry that presents a very sweet and juicy pulp of milky white color [18]. On which they have been made. few investigations to date (four scientific publications, the last one from 2020) [19] About this fruit, it has been reported that it presents various types of antioxidants, mainly polyphenols, flavanones (5,7,3'trihydroxy-6,4,5'-trimethoxyflavanone and 5,3'-dihydroxy$6,7,4,5^{\prime}$ - tetramethoxyflavanone) [20]

In this work, a methodology was developed to determine the antioxidant capacity in wild fruits using Greigia sphacelata as the first model through the pulse difference voltammetry technique, a technique in which the potential is fixed and is superimposed on slowly changing the potential base. The current is measured at two points; before the application of the pulse, and at the end of the pulse [21,22]. The first current is subtracted from the second, and the current difference "I" is plotted against the applied potential.

\section{EXPERIMENTAL METHODOLOGY}

\section{Equipment and Electrodes}

Electrochemical measurements were performed with a Dropsens potentiostat equipped with Dropview 200 software, mounted on an electrochemical cell composed of a glassy carbon working electrode, $3 \mathrm{~mol} \mathrm{~L}^{-1} \mathrm{KCl} \mathrm{Ag} \mathrm{/} \mathrm{AgCl}$ reference electrode and auxiliary wire electrode of platinum, glass cell of length $4 \mathrm{~cm}$, diameter $2.5 \mathrm{~cm}$, volume $20 \mathrm{~mL}$.

\section{ORAC assay}

The antioxidant capacity determinations were carried out with a multi-reader plate spectrophotometer (Epoch-2, Biotek) with a 96-well costar plate, at a wavelength of $540 \mathrm{~nm}$.

\section{Reagents and solutions}

$70 \%$ Methanol solution (methanolic extract preparation), $18.2 \mathrm{M} \Omega . \mathrm{cm}$ ultrapure deionized water, Phosphate buffer solution $(\mathrm{pH}$ 7.4) Solution A: $\mathrm{Na}_{2} \mathrm{HPO}_{4} 1.065 \mathrm{~g}$ in $100 \mathrm{~mL}$ of ultra-pure water, Solution B: $\mathrm{NaH}_{2} \mathrm{PO}_{4} \times \mathrm{H}_{2} \mathrm{O}$ $1.035 \mathrm{~g}$ in $100 \mathrm{~mL}$ of ultra-pure water, adjust solution $\mathrm{A}$ to $\mathrm{pH} 7.4$ with solution $\mathrm{B}$.

RPG $(64 \mu \mathrm{m})$ : weigh $4 \mathrm{mg}$ and dissolve in $10 \mathrm{~mL}$ of buffer, AAPH $(120 \mathrm{mM})$ : weigh $163 \mathrm{mg}$ and dissolve in $1 \mathrm{~mL}$ of buffer, Trolox $(1 \mathrm{mM})$ : weigh $6.25 \mathrm{mg}$ and dissolve in $25 \mathrm{~mL}$ of buffer.

\section{Fruit}

Known as Greigia Sphacelata (Chupón or Quiscal), a fruit obtained commercially at fairs in the city of Temuco, Araucanía region.

\section{Alcoholic extraction of Greigia sphacelata}

Approximately $20 \mathrm{~g}$ of the fruit are freeze-dried under vacuum in the SYCLON-ION equipment under pressure and temperature conditions of 3.0.10${ }^{3} \mathrm{~atm}$ and $38{ }^{\circ} \mathrm{C}$, respectively. Methanolic extractions will be made at $70 \%(\mathrm{v} / \mathrm{v}$, $\mathrm{pH} 2.0$ ) of the lyophilized samples of Greigia sphacelata to obtain the antioxidant compounds [23]. Two grams of the lyophilizate are weighed and dissolved in $10 \mathrm{~mL}$ of the alcoholic solution under stirring for two hours at room temperature. Once the time has elapsed, this mixture is filtered under vacuum, obtaining the extract.

\section{Antioxidant capacity}

The determination of the antioxidant capacity of Greigia sphacelata was carried out by means of the ORAC test with modifications [34]. Prior to the ORAC determination of the aliquots of the methanolic extract of the fruit, a calibration curve is made with the $1 \mathrm{mM}$ Trolox standard, in concentrations of $50,100,200,300,400,500,600 \mu \mathrm{mol} \mathrm{L}^{-1}$. The reaction mix (final volume 250 $\mu \mathrm{L}$ ) contains $194 \mu \mathrm{L}$ of phosphate buffer, $20 \mu \mathrm{L}$ of RPG, and $15 \mu \mathrm{L}$ of diluted sample $(1: 20 \mathrm{v} / \mathrm{v})$. The blank consists of $209 \mu \mathrm{L}$ of phosphate buffer with $20 \mu \mathrm{L}$ of RPG and the reaction control of $230 \mu \mathrm{L}$ of phosphate buffer with $20 \mu \mathrm{L}$ of RPG. The microplate was incubated for 30 minutes at $37^{\circ} \mathrm{C}$, and then an AAPH solution $(21 \mu \mathrm{L})$ was added to all wells except the reaction control. Then the absorbance of the mixtures was measured at $540 \mathrm{~nm}$ everyone minute, for an hour and a half in a microplate multi-reader (Epoch-2, Biotek).
The area under the curve (AUC) of these kinetic data was evaluated by their integration up to a time such that (A / A0) reached a value of 0.2. The result was expressed as micromoles liter of Trolox equivalents (ET).

\section{Electrochemical technical optimization}

The optimization of the electroanalytical technique, using the $1 \mathrm{mM}$ Trolox standard, was carried out in a cell in which $10 \mathrm{~mL}$ of phosphate buffer $\mathrm{pH} 7.4$ and $100 \mu \mathrm{L}$ of each corresponding standard were added, with a concentration of $1 \mathrm{mM}$. , to carry out a monovariate optimization, in which a parameter is varied, leaving the rest of the parameters to be optimized constant.

To obtain the optimal analysis parameters in the electroanalytical technique, specifically in differential impulse voltammetry (DPV), $10 \mathrm{~mL}$ of $0.1 \mathrm{~mol} \mathrm{~L}^{-1}$ phosphate buffer ( $\mathrm{pH} 7.4$ ) was deposited in the cell, with DPV being carried out at a defined potential range between 0.0 and $1.2 \mathrm{~V}$.

The parameters to study are:

$\mathrm{S}_{\text {rate }}: 0.01 ; 0.025 ; 0.05 ; 0.075 ; 0.100 ; 0.250(\mathrm{~V} / \mathrm{s})$

E puls: $_{\text {: }}$ 0.010; 0.050; 0.100; 0.150; 0.200; $0.250(\mathrm{~V})$

$\mathrm{E}_{\text {step: }}: 0.005 ; 0.010 ; 0.025 ; 0.050 ; 0.100 ; 0.250(\mathrm{~V})$

$\mathrm{T}_{\text {puls }}: 5,10,15,20,30,35,40(\mathrm{~ms})$

\section{DPV calibration curve}

Once the working conditions of the voltammetric method were optimized, the calibration curve was carried out with the Trolox standard with a concentration of $1 \mathrm{mmol} / \mathrm{L}$. The electrochemical cell is composed of phosphate buffer $\mathrm{pH} 7.4$ to obtain the baseline and subsequently, aliquots of 50, 100, 200, 300, 400, 500 and $600 \mu \mathrm{L}$ respectively of the Trolox standard are added, each point is performed separately by completing $10 \mathrm{~mL}$ with phosphate, reaching concentration ranges from $50 \mu \mathrm{mol} / \mathrm{L}$ to $600 \mu \mathrm{mol} / \mathrm{L}$. To process the data, the difference in current or load that is obtained after adding an aliquot of the standard and the base current, to this difference in currents or load, must be calculated. Subsequently, $\mathrm{I}(\mu \mathrm{A})$ or $(\mu \mathrm{C})$ versus concentration $\left(\mu \mathrm{mol} \mathrm{L}^{-1}\right)$ was plotted.

The antioxidant capacity determinations through the tests will be carried out in triplicate, the correlation analysis between the conventional tests and the developed test will be carried out using Pearson's correlation at a significance level of $\mathrm{p} \leq 0.05[25,2]$.

\section{RESULTS AND DISCUSSION}

\section{Determination of antioxidant capacity ORAC test}

The calibration curve of the Trolox reference standard (figure 2) was performed to determine the antioxidant capacity in the samples. The calibration curve presented good linearity, presenting detection and quantification limits of $43.8 \mu \mathrm{molL}^{-1}$ and $120 \mu \mathrm{molL}^{-1}$, respectively (figure 3 ). Once the calibration curve was obtained, the antioxidant capacity of the fruits was determined, presenting a concentration of $3525 \mu \mathrm{mol} / 100 \mathrm{~g}$ eq Trolox for Greigia sphacelata.

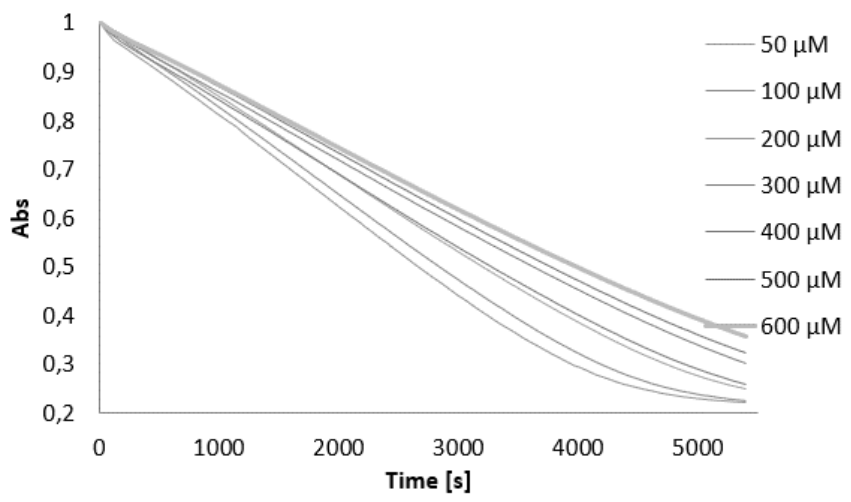

Figure 2. $1 \mathrm{mM}$ Trolox standard ORAC assay calibration curve (absorbance as a function of time). 


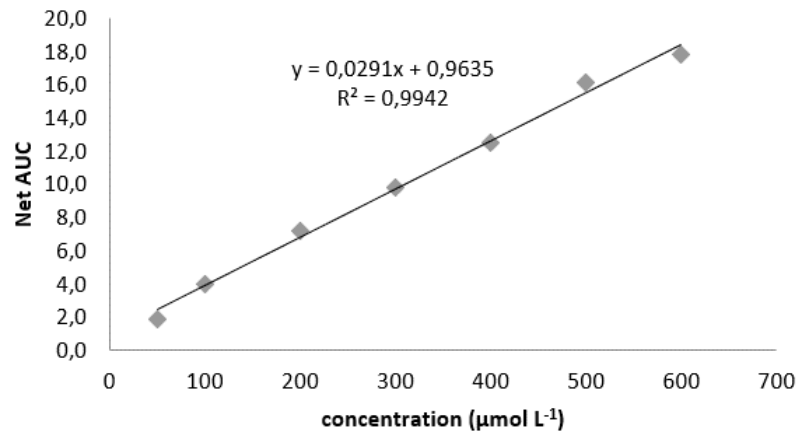

Figure 3. $1 \mathrm{mM}$ trolox standard ORAC assay calibration curve.

\section{DPV voltammetric test}

Once the antioxidant capacity values were obtained, we continued with the study using voltammetric techniques, studying the Trolox standard, differential pulse voltammetry presented good analytical signals, which was selected and optimized to carry out the tests, with phosphate-buffered electrolyte. at $\mathrm{pH}=7.4$, with:

- $\quad \mathrm{S}_{\text {rate }}: 0.05(\mathrm{~V} / \mathrm{s})$

- $\mathrm{E}_{\text {puls: }} 0.100(\mathrm{~V})$

- $\mathrm{E}_{\text {step: }}: 0.010(\mathrm{~V})$

- $\mathrm{T}_{\text {puls }}: 35(\mathrm{~ms})$.

With these conditions, the standard presented good signals, presenting the Trolox standard analytical signal at a potential of $200 \mathrm{mV}$ vs. $\mathrm{Ag} / \mathrm{AgCl}$ (figure 4). Then the standard curve was performed by means of the relationship of the load as a function of the concentration, showing good linearity, with detection and quantification limits of $39.3 \mu \mathrm{mol} \mathrm{L} \mathrm{L}^{-1}$ and $109 \mu \mathrm{mol} \mathrm{L^{-1 }}$ respectively (figure 5), determining in the matrix a concentration of $724 \mu \mathrm{mol} / 100 \mathrm{~g}$ eq Trolox for Greigia sphacelata.

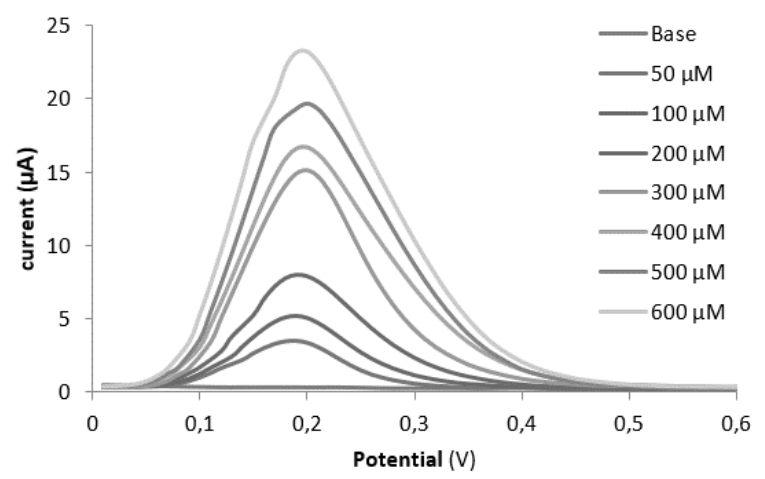

Figure 4. Differential pulse voltammetry (DPV), Trolox standard calibration curve. Scan rate $50 \mathrm{mV} / \mathrm{s}$

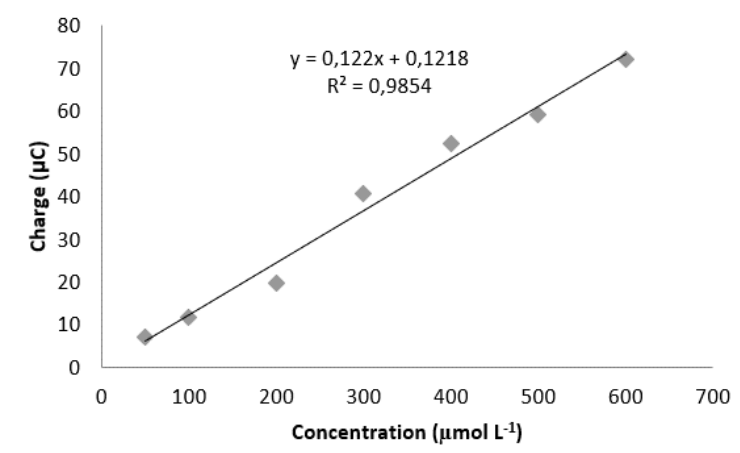

Figure 5. $1 \mathrm{mM}$ trolox standard DPV assay calibration curve (charge as a function of concentration).
Once the ORAC and DPV calibration curves were obtained, the correlation between both methods was studied (Figure 6), which shows a good correlation with an $r$ value equal to 0.989 .

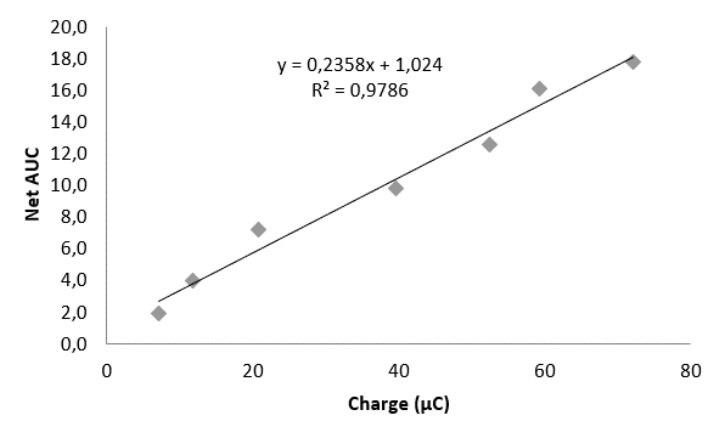

Figure 6. Correlation area under the curve - standard coulombic charge trolox $1 \mathrm{mM}$ ORAC-DPV assays.

The ORAC test of the Greigia sphacelata extract (figure 7) shows a linear increase in the area under the curve with respect to the increase in the aliquot of the extract as a function of time in most of them. In the case of differential pulse voltammetry (Figure 8), it shows us various oxidation peaks as the aliquot of the added extract increases, with oxidation peaks at approximately $0.270 \mathrm{~V}, 0.430$ $\mathrm{V}$, and $0.880 \mathrm{~V}$.

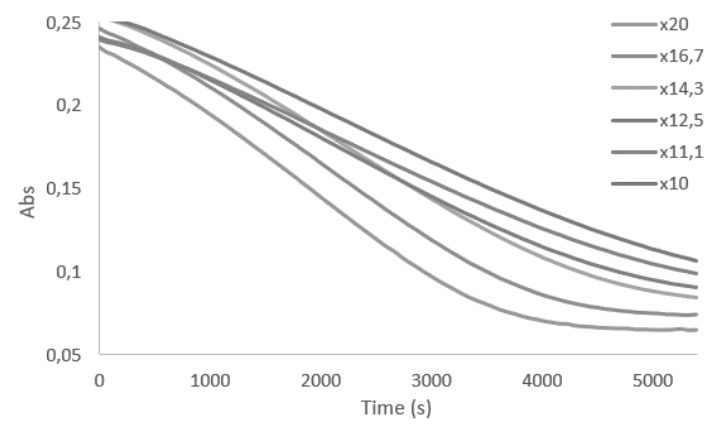

Figure 7. Absorbance as a function of time ORAC Greiga Sphacelata assay (Chupón).

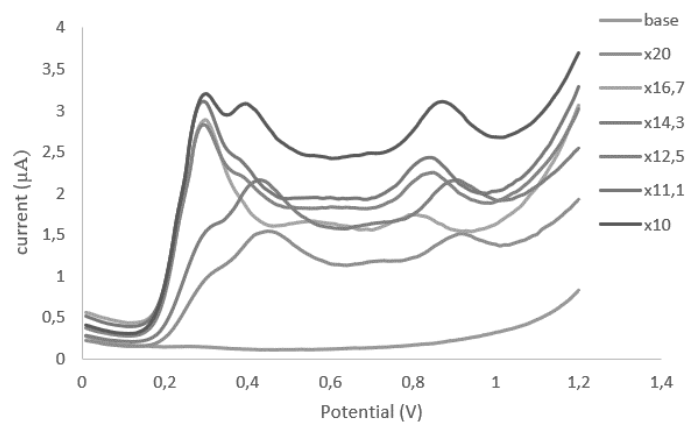

Figure 8. DVP aliquots of Methanolic Greiga Sphacelata extract. (Chupón). Scan rate $50 \mathrm{mV} / \mathrm{s}$

Table 1. Data obtained, net values of area under the curve (NET AUC, ORAC assay), of coulombic load (DPV assay), and their respective concentrations extrapolated from the calibration curve of antioxidant capacity tests for Greiga Sphacelata extract.

\begin{tabular}{|c|c|c|c|}
\hline $\begin{array}{c}\text { NET } \\
\text { AUC }\end{array}$ & $\begin{array}{c}\text { Charge } \\
(\boldsymbol{\mu} \mathbf{C})\end{array}$ & $\begin{array}{c}\text { Concentration NET } \\
\mathbf{A U C}\left(\boldsymbol{\mu} \mathbf{m o l ~ L}^{-\mathbf{1}}\right)\end{array}$ & $\begin{array}{c}\text { Concentration charge } \\
\left(\boldsymbol{\mu} \mathbf{m o l ~ \mathbf { L } ^ { - 1 }}\right)\end{array}$ \\
\hline 4.14 & 6.03 & 32.9 & 140.7 \\
\hline 4.88 & 7.58 & 39.0 & 222.0 \\
\hline 6.58 & 10.0 & 52.9 & 348.9 \\
\hline 7.59 & 11.5 & 61.2 & 429.3 \\
\hline 8.28 & 13.2 & 66.8 & 516.5 \\
\hline 10.8 & 14.2 & 87.5 & 569.5 \\
\hline
\end{tabular}


For the correlation of the voltammetric (DPV) and spectrophotometric method using the extract of Greigia sphacelata, several determinations of various aliquots (Table 1) of the extract were made, obtaining its area under the curve in ORAC (figure 7) and the DPV voltammograms (figure 8) arriving to determine the correlation Coulombic Charge-area under the curve (DPV-ORAC) and the concentrations obtained in Trolox equivalents (DPV-ORAC), both presenting a correlation $r$ of 0.969 (figures 9 and 10).

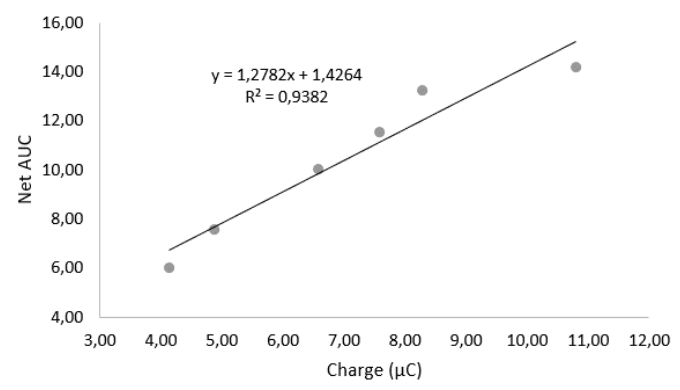

Figure 9. Correlation net value area under the curve (ORAC)-coulombic charge (DPV) in study of an extract of Greiga Sphacelata. (Chupón).

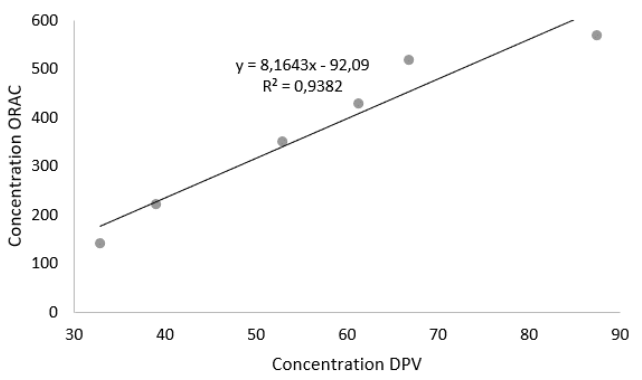

Figure 10. Concentration (ORAC) vs. concentration (DPV) correlation in the study of Greiga sphacelata extract. (Chupón).

\section{DISCUSSION}

The results obtained leave us as a conclusion that the Greigia sphacelata fruit (Chupón or Quiscal) has a low antioxidant capacity carried out by the ORAC method, which is reinforced with that obtained by differential pulse voltammetry (DPV), expressed in $\mu \mathrm{molL}^{-1}$ equivalent of Trolox, but an aspect to highlight is the correlation that occurs between the methods, both with the study of the Trolox standard and in the determination of the antioxidant capacity of the matrix studied, it should be noted that the differential voltammetry of pulses at presented good results for the study of antioxidant capacity, leaving the door open to continue innovating and optimizing this technique to be an established method for the determination of antioxidant capacity in various matrices.

\section{ACKNOWLEDGMENT}

The authors thank the Faculty of Chemical Sciences of the University of Concepción for giving the opportunity to carry out this work. FA thanks to Department of Food Science and Technology, Faculty of Pharmacy of the University of Concepción for allowing the development of fundamental experiments in this work.

\section{REFERENCES}

1. Hernández-García, D., Wood, C. D., Castro-Obregón, S., \& Covarrubias, L. (2010). Reactive oxygen species: a radical role in development?. Free Radical Biology and Medicine, 49(2), 130-143.

2. Apak, R., Özyürek, M., Güçlü, K., \& Çapanoğlu, E. (2016). Antioxidant activity/capacity measurement. 1. Classification, physicochemical principles, mechanisms, and electron transfer (ET)-based assays. Journal of Agricultural and Food Chemistry, 64(5), 997-1027.

3. Bala, M., Troja, R., \& Dalanaj, N. (2017). Antioxidant effects of natural bioactive compounds. Journal of Hygienic Engineering and Design, 18, 5962 .

4. Begović, N., Mojović, M., \& Marković, Z. S. (2017). Antiradical activity of delphinidin, pelargonidin and malvin towards hydroxyl and nitric oxide radicals : the energy requirements calculations as a prediction of the possible antiradical mechanisms. Food Chemistry, 218, 440-446.

5. Zheng, Y., Deng, G., Chen, D., Liang, Q., Guo, R., \& Fu, Z. (2017). Theoretical studies on the antioxidant activity of pinobanksin and its ester derivatives: effects of the chain length and solvent. Food Chemistry, 240, 323 -329 .

6. Chen, J., Yang, J., Ma, L., Li, J., Shahzad, N., \& Kim, C. K. (2020). Structureantioxidant activity relationship of methoxy, phenolic hydroxyl, and carboxylic acid groups of phenolic acids. Scientific Reports, 10, article number 2611, p. 1-9.

7. Apak, R., Güçlü, K., Demirata, B., Özyürek, M., Çelik, S. E., Bektaşoğlu, B., Berker, K. I., \& Özyurt, D. (2007). Comparative evaluation of various total antioxidant capacity assays applied to phenolic compounds with the CUPRAC assay. Molecules, 12(7), 1496-1547. https://doi.org/10.3390/12071496

8. Prior, R. L. (2015). Oxygen radical absorbance capacity (ORAC): New horizons in relating dietary antioxidants/bioactives and health benefits. Journal of functional foods, 18, 797-810.

9. Londoño Londoño, J. (2012). Antioxidantes: importancia biológica y métodos para medir su actividad. In Desarrollo y Transversalidad serie Lasallista Investigación y Ciencia. Corporación Universitaria Lasallista.

10. Ziyatdinova, G., Salikhova, I., Skorobogatova, N., Chibisova, M., \& Budnikov, H. (2015). New Electrochemistry-Based Approaches to Brandy Quality Evaluation Using Antioxidant Parameters. Food Analytical Methods, 8(7), 1794-1803.

11. Haque, M. A., Morozova, K., Lawrence, N., Ferrentino, G., \& Scampicchio, M. (2020). Radical Scavenging Activity of Antioxidants by Cyclic Voltammetry. Electroanalysis, 1-7.

12. Deutchoua, A. D. D., Siegnin, R., Kouteu, G. K., Dedzo, G. K., \& Ngameni, E. (2019). Electrochemistry of 2,2-Diphenyl-1-picrylhydrazyl (DPPH) in Acetonitrile in Presence of Ascorbic Acid - Application for Antioxidant Properties Evaluation. ChemistrySelect, 4(46), 13746-13753.

13. Schilder, W. H., Tanumihardja, E., Leferink, A. M., Berg, A. Van Den, \& Olthuis, W. (2020). Heliyon Determining the antioxidant properties of various beverages using staircase voltammetry - E + E. Heliyon, 6(January), e04210.

14. Iqbal, S., Perveen, S., \& Mohiuddin, S. (2020). Antioxidant studies of citric acid and citrus fruits towards paraquat by cyclic voltammetry: An antidote of paraquat poisoning. Pak J Pharm Sci, 33(1(Supplementary)),263-267.

15. Hornung-leoni, C. T. (2011). Bromeliads: traditional plant food in latin america since prehispanic times. Polibotánica, N32, 219-229.

16. Elgueta, E. I., Valenzuela, J., \& Rau, J. R. (2007). New insights into the prey spectrum of Darwin's fox (Pseudalopex fulvipes Martin, 1837) on Chiloé Island, Chile. Mammalian Biology, 72(3), 179-185.

17. Will, B., \& Zizka, G. (1999). A review of the genus Greigia regel (Bromeliaceae) in Chile. Harvard Papers in Botany, 4(1), 225-239.

18. Rapaport, E.H., Ladio, A and E.H. Sanz, 2003. Plantas nativas comestibles de la Patagonia Andina Argentino/Chilena. Parte II. Programa de Extensión Universitaria. Universidad Nacional del Comahue. Ediciones de Imaginaria. Argentina. 30 pp.

19. Barrientos, R. E., Ahmed, S., Cortés, C., \& Fernández-galleguillos, C. (2020) Chemical Fingerprinting and Biological Evaluation of the Endemic Chilean Fruit Greigia sphacelata (Ruiz and Pav.) Regel (Bromeliaceae) by UHPLCPDA- Orbitrap-Mass Spectrometry. Molecules, 25(16), 3750.

20. Flagg, M. L., Wächter, G. A., Davis, A. L., Montenegro, G., \& Timmermann, B. N. (2000). Two novel flavanones from Greigia sphacelata. Journal of Natural Products, 63(12), 1689-1691.

21. Wang, Joseph. (2006). Analytical electrochemistry: John Wiley \& Sons.

22. Osteryoung, Janet G, \& Osteryoung, Robert A. (1985). Square wave voltammetry. Analytical Chemistry, 57(1), 101A-110A.

23. Jiao, Y., Kilmartin, P. A., Fan, M., \& Young, S. (2018). Assessment of phenolic contributors to antioxidant activity of new kiwifruit cultivars using cyclic voltammetry combined with HPLC. Food Chemistry, 268, 77-85.

24. Ortiz, R., Antilén, M., Speisky, H., Aliaga, M. E., López-Alarcón, C., \& Baugh, S. (2012). Application of a microplate-based ORAC-pyrogallol red assay for the estimation of antioxidant capacity: first action 2012.03. Journal of AOAC International, 95(6), 1558-1561.

25. Restrepo, L., \& Gonzáles, J. (2007). From Pearson to Spearman. Revista Colombiana de Ciencias Pecuarias, 20(2), 183-192. 